\title{
IMAGINEA TINERILOR DESPRE OMUL RELIGIOS. REPERE PENTRU EDUCAŢIA MORALĂ ŞI EDUCAŢIA RELIGIOASĂ
}

\author{
Monica Opriş \\ Dorin Opriş
}

\begin{abstract}
The teenagers' conception about the religious man. Benchmarks for moral and religious education. The expectations regarding Religion school subject belong to religious experience, evidenced by the presence of children and young people in church services, which is an important fact in the life of a Christian. Starting from the necessity of some data to sustain the construction of the new curriculum of Religion subject for secondary and high school, we realized a research to find out how we could support the formation of the religious man, from the perspective of high school students. Also, our aim was to offer to Christian teachers those data needed to facilitate their approach to identify ways in which they may help students to make the transition to the theoretical knowledge to the living of faith, reflected in elements of internal and external religiosity. In this study, we present an analysis related to characteristics of the religious man, based on the data from more than 800 high school students with different variables (gender, residence, social class, educational level, religious denomination).
\end{abstract}

Keywords: religious man, faith, religious education, curriculum, religious values.

\section{Premise}

Rezultatele cercetării World Values Survey, realizate cu scopul identificării valorilor şi a impactului acestora asupra vieţii

* PhD, Professor, „St. Simion Ştefan” The Orthodox Theological Seminary, Alba Iulia, Romania.

** PhD, Assistant Professor, Teaching Staff Professional Training Department of Orthodox Theology at "1 Decembrie 1918" University in Alba Iulia. 
sociale şi politice ${ }^{1}$, au generat în media românească multiple comentarii, dată fiind poziţia de prim rang ocupată de valorile religioase în rândul populaţiei din România. În cadrul cercetării amintite, părinţii au precizat valorile pe care le consideră importante pentru educaţia copiilor lor, cele mai importante dintre acestea fiind respectul faţă de valorile religioase, munca şi cumpătarea.

Din punctul nostru de vedere, acest rezultat al cercetării poate fi considerat şi un răspuns la întrebarea „Care sunt efectele predării religiei în şcoală?" deoarece, de cele mai multe ori, expectanţele referitor la această disciplină de învăţământ se înscriu pe linia efectivităţii trăirii religioase, manifestată prin prezenţa la slujbele bisericii, de altfel fapt deosebit de important în viaţa unui creştin.

Pornind de la aceste date, dar şi de la nevoia unor cercetări care să asigure suportul construcţiei noului curriculum de religie la gimnaziu şi liceu, am realizat o cercetare privind profilul omului religios, din perspectiva liceenilor. Totodată, ne-am propus să oferim educatorilor din domeniul religios date utile în demersul de identificare a modalităţilor prin care să îi ajute pe elevi să treacă din planul cunoaşterii de tip teoretic şi de la cel al interiorizării credinţei, la cel al manifestării, al exteriorizării acesteia.

În studiul de faţă, prezentăm o analiză în funcţie de diferite variabile (gen, mediu de rezidenţă, clasă, nivel de instruire, confesiune) a răspunsurilor oferite de 803 liceeni din judeţul Alba, la itemul „Scrieţi trei caracteristici ale omului religios”.

\section{1. Însuşirile principale ale omului religios}

Definiţia „Omul este fiinţă religioasă” (Homo religiosus), dată de istoricul religiilor Mircea Eliade rezumă adevărul punerii în relaţie a omului cu Dumnezeu, prin actul creaţiei. Paleta de accepţiuni a ceea ce înseamnă a fi religios are o amplitudine mare, care pleacă de la a susţine un set de crezuri la care omul aderă în plan

${ }^{1}$ În România, datele cercetării au fost prezentate în lucrarea Daniel David, Psihologia poporului român. Profilul psihologic al românilor într-o monografie cognitiv-experimentală, Iaşi, Editura Polirom, 2015. 
teoretic, până la plasarea în planul cunoaşterii prin iubire a lui Dumnezeu, care presupune un parcurs, o dinamică a vieţii spirituale ce începe cu credinţa şi se continuă cu manifestarea acesteia prin fapte, în paralel cu dobândirea virtuţilor. În această ultimă accepţiune, caracteristică spiritualităţii ortodoxe, a fi om religios presupune a fi om credincios, care urcă spiritual spre omul înduhovnicit, până ajunge la sfinţenie ${ }^{2}$.

Opţiunea pentru un item deschis este recomandată de posibilitatea alcătuirii unei liste cu însuşirile omului religios şi ierarhizarea acestora în funcţie de frecvenţa cu care apar (tabelul 1).

\section{Ierarhia însuşirilor omului religios, Tabelul 1 după totalul alegerilor}

\begin{tabular}{|l|c|c|}
\hline Însuşiri ale omului religios & Total & \% \\
\hline să creadă în Dumnezeu & 475 & 59,15 \\
\hline să meargă la biserică & 209 & 26,02 \\
\hline să se roage & 187 & 23,28 \\
\hline să fie iubitor de aproapele său & 171 & 21,29 \\
\hline să fie smerit & 146 & 18,18 \\
\hline să fie înţelept & 111 & 13,82 \\
\hline să fie sincer & 56 & 6,97 \\
\hline să fie respectuos & 32 & 3,98 \\
\hline să fie exemplu pentru ceilalţi & 29 & 3,61 \\
\hline să fie iertător & 25 & 3,11 \\
\hline să aibă frică de Dumnezeu & 25 & 3,11 \\
\hline să fie postitor & 20 & 2,49 \\
\hline să fie blând & 16 & 1,41 \\
\hline să fie harnic & 14 & 1,24 \\
\hline să fie cumpătat & 4 & 0,3 \\
\hline
\end{tabular}

Pe baza datelor din tabelul 1, putem face următoarele observaţii:

${ }^{2}$ Dumitru Stăniloae, Ascetica şi mistica ortodoxă, Alba Iulia, Editura Deisis, Mănăstirea Sf. Ioan Botezătorul, 1993, p. 8. 
- Numărul total al răspunsurilor primite (1520) arată că nu toţi elevii au precizat trei însuşiri, media pentru întreg eşantionul fiind 1,89.

- Credinţa în Dumnezeu a fost prezentă în lista majorităţii elevilor $(59,15 \%)$, aceasta fiind plasată pe primul loc în lista însuşirilor la $41,84 \%$ din totalul respondenţilor.

- Analiza valorilor procentuale arată că următoarele însuşiri (începând cu să meargă la biserică) pot fi încadrate în trei intervale de frecvenţă: între 20-30\% (3 însuşiri), între 10-20\% (2 însuşiri), respectiv între $0,3-10 \%$ (9 însuşiri).

- Dacă analizăm conţinutul însuşirilor din punct de vedere teologic, constatăm că unele sunt reprezentate de virtuţi (credinţa, iubirea, smerenia, respectul, blândeţea, înţelepciunea, cumpătarea, hărnicia, frica de Dumnezeu, exemplul personal), iar altele ţin de manifestarea credinţei prin acte de cult (participarea la biserică, rostirea de rugăciuni, ţinerea postului).

Din punct de vedere creştin ortodox, postul este un element de religiozitate important. Prezenţa însuşirii de a posti la un număr mic de elevi din eşantion poate fi pusă pe seama lipsei acestei preocupări religioase în viaţa familiilor lor. Profilul celor care au precizat postul în şirul celor trei însuşiri ale omului religios este următorul: fată din mediul urban sau rural, cu nivel mediu de instruire, din clasa a IX-a sau a XI-a, de confesiune ortodoxă.

Absenţa din lista realizată pe baza răspunsurilor elevilor a unor însuşiri precum răbdarea ${ }^{3}$ sau nădejdea reflectă o stare de fapt, observată de educatori la tineri, nu doar pe aspecte religioase: dorinţa de a obţine imediat rezultate, de reuşite, chiar fără o implicare personală semnificativă, superficialitate în demersurile întreprinse, lipsa unui ideal, incapacitatea majorităţii de a se antrena în proiecte pe termen lung, lipsa rezistenţei la efort intelectual şi fizic. Toate acestea, conduc spre nevoia unor acţiuni de educare a răbdării, de valorizare a idealului în viaţă, de ancorare a vieţii în Dumnezeu.

În continuare, vom analiza datele pentru însuşirile prezente într-un procent mai mare de $10 \%$, în funcţie de diferite variabile.

${ }^{3}$ Dorin Opriş, Monica Opriş, Teenagers'models of understanding suffering, in: European Journal of Science and Theology, 8:2, 2012, p. 173-182. 


\section{$15^{\text {th }}$ International Symposium on Science, Theology and Arts}

Considerăm că propunerile făcute de elevi reflectă, în mare parte, şi starea lor sufletească, dar şi modele de religiozitate observate la cei din jur.

\section{Analiza însuşirilor omului religios, în funcţie de gen}

Cercetările din România privind valorile religioase arată tendinţa de diminuare a diferenţelor în funcţie de gen la populaţia tânără. Lista celor şase însuşiri ale omului religios precizate de elevii din eşantionul nostru sunt trecute în tabelul 2, pe baza căruia am realizat diagrame de comparaţie (figura 1). Diferenţele mai mari de 5\% le-am marcat cu bold.

Însuşirile omului religios,

Tabelul 2

în funcţie de gen

\begin{tabular}{|l|c|c|}
\hline Însuşiri ale omului religios & Băieți & Fete \\
\hline să creadă în Dumnezeu (c) & $\mathbf{6 3 , 4 2}$ & $\mathbf{5 7 , 7 7}$ \\
\hline să meargă la biserică (b) & 24,77 & 27,33 \\
\hline să se roage (r) & 23,59 & 23,77 \\
\hline să fie iubitor de aproapele său (i) & $\mathbf{1 7 , 6 9}$ & $\mathbf{2 4 , 6 6}$ \\
\hline să fie smerit (s) & 17,10 & 19,55 \\
\hline să fie înţelept (î) & $\mathbf{1 0 , 6 1}$ & $\mathbf{1 6 , 4 4}$ \\
\hline
\end{tabular}

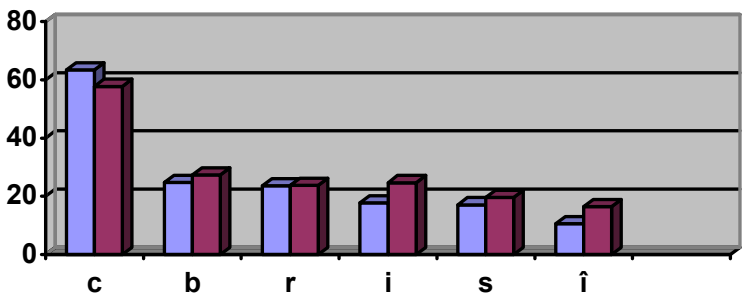

$\square$ băieţi

$\square$ fete

Fig.1. Diagrame de comparaţie privind principalele caracteristici ale omului religios, în funcţie de genul elevilor $(c=$ credincios; $b=$ bisericos; $r=$ rugător; $i$ = iubitor de semeni; $\mathrm{s}=$ smerit; $\hat{i}=$ înţelept)

Principalele observaţii care pot fi făcute sunt următoarele: 
- Diferenţe mai mari de 5\% apar la trei din cele şase însuşiri: credinţa, iubirea semenilor, înţelepciunea, prima în favoarea băieţilor, iar ultimele două în favoarea fetelor.

- Însuşirile legate de manifestarea credinţei în public, respectiv în particular au procente apropiate, la diferenţe sub trei puncte procentuale.

Dacă analizăm diferenţele procentuale, datele obţinute de noi confirmă conceptele psihologiei: băieţii se regăsesc mai mult în aspectele practice ale vieţii religioase, iar fetele sunt caracterizate îndeosebi de sensibilitatea faţă de semeni. Implicarea femeii în viaţa socială cunoaşte în ultimul timp o dezvoltare accentuată, fapt susţinut şi de formarea în şcoală a unor competenţe decizionale, ceea ce poate să explice prezenţa într-un procent mai mare decât la băieţi a înţelepciunii în lista însuşirilor unui creştin.

Procentele foarte apropiate pentru participarea la slujbele bisericeşti, rugăciune şi smerenie arată tendinţa la tânăra generaţie de egalizare în ceea ce priveşte practica religioasă. Dacă la persoanele adulte frecvenţa participării este favoarea femeilor, pentru tânăra generaţie, diferenţele sunt reduse, posibil şi ca efect al studierii religiei în şcoală.

\section{Analiza însuşirilor omului religios, în funcţie de mediul de rezidenţă}

Cercetările sociologice din România au vizat numeroase aspecte legate de practica religioasă. Astfel, o perspectivă în plan longitudinal, începând cu anul 1993, privind frecvenţa participării lunare la biserică relevă următoarea realitate: „În România practica religioasă a înregistrat o creştere constantă, procentul celor care merg la biserică lunar crescând de la 30\% în 1993 la 48\% în 2008. Datele de sondaj relevă un «salt» al practicii religioase în prima parte a tranziţiei post-comuniste, când ponderea celor care declară că merg la biserică lunar creşte cu $16 \%$ în decurs de 6 ani. În ultimii nouă ani, practica religioasă înregistrează un platou, ponderea celor care participă la serviciile religioase lunar fiind constantă. Spre deosebire însă de studiile anterioare, care indicau o incidenţă mai crescută a 
practicii religioase în rândul populaţiei rurale, datele culese în 2008 arată o egalizare a frecventării bisericii în cele două medii rezidenţiale. În timp ce în 1999 53\% dintre rezidenţii din mediul rural afirmau că participă la serviciile religioase lunar, în 2008 ponderea acestora se reduce cu $5 \%$. În schimb orăşenii devin mai «bisericoşi» în aceeaşi perioada, procentul înregistrat în 2008 fiind cu 7\% mai ridicat decât cel din 1999. [...] Deşi tendinţa «naturală» este să atribuim valori mai ridicate ale credinţei şi practicii religioase celor vârstnici, pentru că au crescut într-o societate mai tradiţională şi pentru că atunci când îmbătrânești te gândești mai des la «cele sfinte», datele referitoare la religiozitatea românilor nu susţin neapărat această tendinţă" ${ }^{4}$.

Aceste procente ne oferă un cadru ştiinţific de comparare a datelor obţinute de noi în ceea ce priveşte analiza în funcţie de mediul de rezidenţă, sintetizate în tabelul 3 şi în diagramele de comparaţie din figura 2 .

\section{Însuşirile omului religios, \\ Tabelul 3 \\ în funcţie de mediul de rezidenţă}

\begin{tabular}{|l|c|c|}
\hline Însuşiri ale omului religios & Urban & Rural \\
\hline să creadă în Dumnezeu (c) & 61,21 & 58,83 \\
\hline să meargă la biserică (b) & 26,31 & 28,53 \\
\hline să se roage (r) & 25,07 & 21,96 \\
\hline să fie iubitor de aproapele său (i) & 21,88 & 22,47 \\
\hline să fie smerit (s) & 19,39 & 17,92 \\
\hline să fie înţelept (î) & 12,74 & 15,15 \\
\hline
\end{tabular}

${ }^{4}$ Mălina Voicu (ed.), Credinţă şi practică religioasă în România, Institutul de Cercetare a Calităţii Vieţii, Grupul românesc pentru studiul valorilor sociale, „Valorile românilor”, Newsletter, nr. 2, februarie, 2009, p. 1-2. 


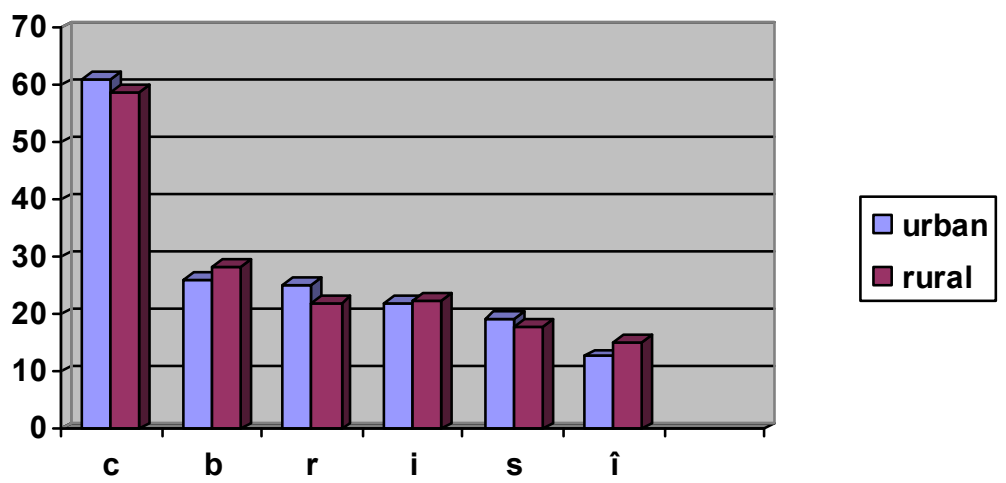

Fig.2. Diagrame de comparaţie privind principalele caracteristici ale omului religios, în funcţie de mediul de rezidenţă $(c=$ credincios; $b=$ bisericos; $r=$ rugător; $i=$ iubitor de semeni; $s=$ smerit; $\hat{i}=$ înţelept $)$

Analiza datelor în funcţie de mediul de rezidenţă arată diferenţe mai mici de 5 puncte procentuale pentru toate însuşirile omului religios $^{5}$, fapt în conformitate şi cu rezultatele altor cercetări ${ }^{6}$. Rezultatele sunt foarte apropiate de cele obţinute pentru întreg eşantionul de subiecţi.

\section{Analiza însuşirilor omului religios, în funcţie de clasa în care sunt înscrişi elevii}

Parcursul religios al elevilor de liceu nu este unul liniar. Criza adolescenţei, care însoţeşte toată perioada liceului are perioade de maximum în clasa a X-a şi a XI-a, motiv pentru care am analizat datele şi din perspectiva clasei din care fac parte elevii. Datele au fost sintetizate în tabelul 4 şi ilustrate în diagramele de comparaţie din

\footnotetext{
${ }^{5}$ Dorin Opriş, Monica Opriş, Valori, modele şi aşteptări ale liceenilor din judetul Alba, Cluj-Napoca, Editura Eikon, 2015, p. 28.

${ }^{6}$ Vezi şi cercetarea Monica Cuciureanu, Simona Velea (coord.), Educaţia moral-religioasă în sistemul de educaţie din România, Bucureşti, Editura Didactică şi Pedagogică, 2012, p. 27-60.
} 


\section{$15^{\text {th }}$ International Symposium on Science, Theology and Arts}

figura 3. Însuşirile care se diferenţiază pozitiv sau negativ prin valori ce depăşesc cinci puncte procentuale au fost marcate cu bold.

\section{Însuşiri ale omului religios,}

Tabelul 4

în funcţie de clasa din care fac parte elevii

\begin{tabular}{|l|c|c|c|c|c|}
\hline \multicolumn{1}{|c|}{$\begin{array}{c}\text { Însuşiri ale } \\
\text { omului religios }\end{array}$} & \multicolumn{4}{|c|}{ Clasa } & $\begin{array}{c}\text { Amplitu- } \\
\text { dinea }\end{array}$ \\
\cline { 2 - 6 } & a IX-a & $\mathbf{a}$ X-a & $\mathbf{a}$ XI-a & $\begin{array}{c}\text { a XII- } \\
\text { a }\end{array}$ & \\
\hline $\begin{array}{l}\text { să creadă în } \\
\text { Dumnezeu (c) }\end{array}$ & 62,97 & 58,64 & 54,27 & $\mathbf{6 6 , 2 1}$ & 11,94 \\
\hline $\begin{array}{l}\text { să meargă la } \\
\text { biserică (b) }\end{array}$ & 28,93 & 25,30 & 30,76 & $\mathbf{1 6 , 2 1}$ & 14,55 \\
\hline să se roage (r) & $\mathbf{2 8 , 5 1}$ & $\mathbf{1 5 , 4 3}$ & 24,78 & 23,64 & 13,08 \\
\hline $\begin{array}{l}\text { să fie iubitor de } \\
\text { aproapele său (i) }\end{array}$ & 22,54 & 21,60 & $\mathbf{1 6 , 1 6}$ & 20,94 & 6,38 \\
\hline să fie smerit (s) & 15,31 & 17,90 & $\mathbf{2 3 , 9 3}$ & 15,54 & 8,62 \\
\hline să fie înţelept (î) & 12,76 & $\mathbf{1 9 , 1 3}$ & 11,53 & $\mathbf{7 , 4 3}$ & 11,7 \\
\hline
\end{tabular}

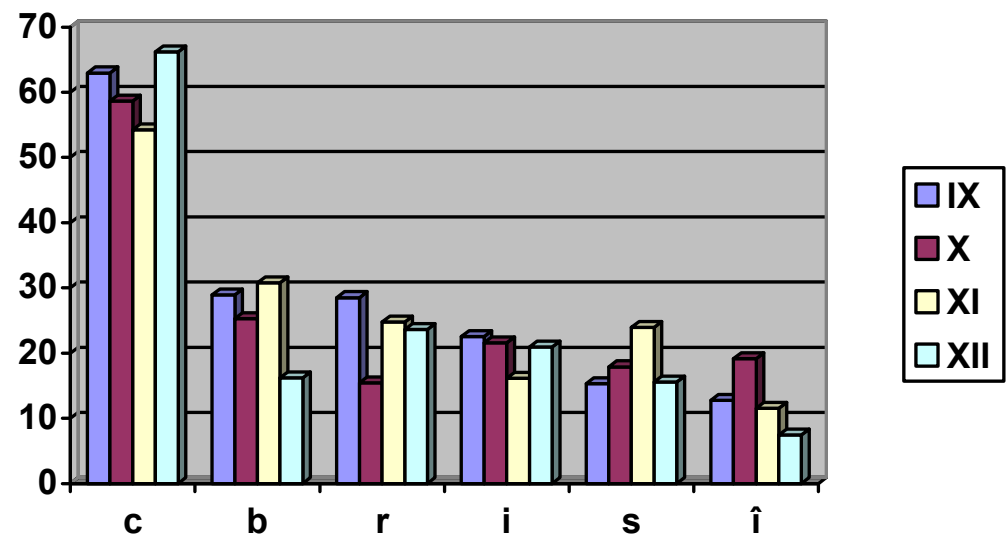

Fig.3. Diagrame de comparaţie privind principalele caracteristici ale omului religios, în funcţie de clasa din care fac parte elevii $(c=$ credincios; $b=$ bisericos; $r=$ rugător; $i=$ iubitor de semeni; $s=$ smerit; $\hat{i}=$ înţelept) 
Pentru fiecare din însuşiri am calculat amplitudinea, care ne ajută să observăm diferenţele între valoarea maximă şi cea minimă pe parcursul şcolarităţii. Pentru patru din cele şase însuşiri amplitudinea depăşeşte zece puncte procentuale, valoarea maximă înregistrată fiind de $14,55 \%$ (în cazul participării la slujbele bisericeşti), fapt care arată modificări în percepţia religioasă de la o clasă la alta, dar şi aspecte de adâncire a crizei religioase pe diferite componente la una sau alta din clase.

Dacă analizăm rezultatele pentru fiecare însuşire în relaţie cu media acestora (tabelul 1), observăm valori care se abat negativ sau pozitiv cu mai mult de cinci puncte procentuale: la clasa a IX-a rugăciunea $(+)$, la clasa a X-a, rugăciunea $(-)$ şi înţelepciunea $(+)$, la clasa a XI-a iubirea faţă de semeni (-) şi smerenia $(+)$, iar la clasa a XII-a credinţa $(+)$, participarea la biserică $(-)$ şi înţelepciunea (-). Aceste date arată prezenţa crizei religioase la clasa a X-a şi a XI-a.

În ceea ce priveşte clasa a XII-a, rezultatele trebuie analizate mai complex. Observăm că, spre deosebire de celelalte clase, dar şi de medie, se diminuează numărul de însuşiri cu procente mai mari de $10 \%$ şi se schimbă semnificativ ierarhia: credinţa are procentul cel mai mare, celelalte patru însuşiri fiind grupate procentual câte două, rugăciunea şi iubirea semenilor, respectiv participarea la biserică şi smerenia.

Dacă considerăm participarea la biserică drept element al religiozităţii externe, iar rugăciunea al celei interne, putem face o analiză a dinamicii în timp a celor două aspecte ale vieţii religioase. Vom utiliza curbele de distribuție a procentelor celor două însuşiri pe parcursul şcolarităţii (fig. 4). 


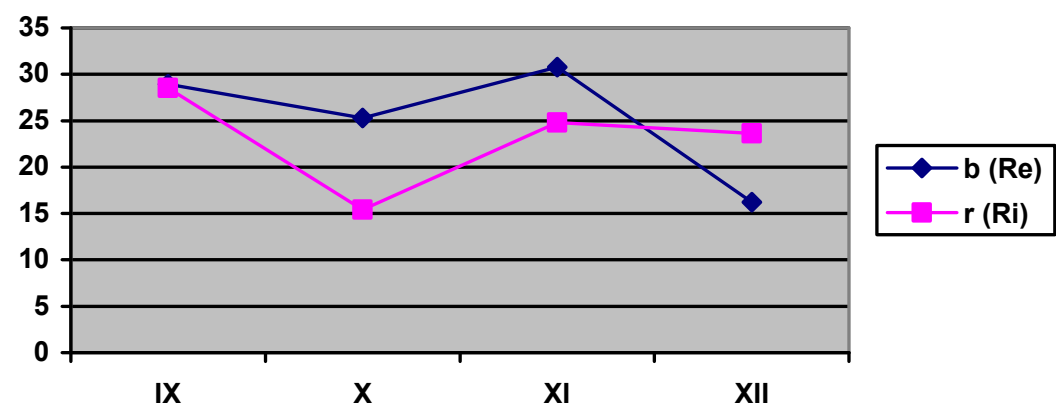

Fig.4. Curbe de distribuţie privind evoluţia în timp a procentelor primite de caracteristicile legate de cele două elemente esenţiale ale religiozităţii externe (participarea la biserică - b), respectiv a celei interne (rugăciune - r)

Dacă în clasa a XI-a elementele de religiozitate externă şi cele de religiozitate internă sunt foarte apropiate ca valoare procentuală, în clasele a X-a şi a XI-a avem o diferenţă pozitivă, pentru ca în clasa a XII-a, aceasta să devină negativă, primând preocuparea pentru interiorizarea credinţei ${ }^{7}$.

Datele de la clasa a XII-a pot fi puse în relaţie cu faptul că elevii acordă mai puţin timp participării la biserică (punctajul cel mai mic) pornind şi de la modificarea priorităţilor legate de apropierea examenului de bacalaureat, a cărui pregătire presupune timp suplimentar.

7 În lucrarea: Monica Opriş, Adolescenţii de azi şi valorile religios-morale. Rolul sfântului ocrotitor al clasei în dezvoltarea spirituală a liceenilor, apărută în volumul: Adrian Lemeni (coord.), „Repere ale educaţiei creştine în teologia Sfântului Ioan Gură de Aur, actualizate în relaţia Biserică-Familie-Şcoală din contextul contemporan", Bucureşti, Editura Basilica, 2015, p. 203-220, este prezentat un model de bune practici prin care elevii de liceu pot fi ajutaţi să parcurgă drumul de la cunoaşterea comună a valorilor religioase realizată în spaţiul şcolar, înspre trăirea acesteia în plan personal şi comunitar în cadrul programului zilnic de rugăciune practicat la Seminarul Teologic Ortodox „Sf. Simion Ştefan" din Alba Iulia. 


\section{Analiza însuşirilor omului religios, în funcţie de nivelul de instruire}

Analiza datelor în funcţie de nivelul de instruire reflectă câteva diferenţe faţă de medie, majoritatea la elevii cu medii mici, pe următoarele componente: rugăciunea $(18,46 \%)$, iubirea faţă de semeni $(16,92 \%)$, smerenia $(10,76 \%)$. Din cele trei însuşiri, pentru iubirea faţă de semeni avem procent apropiat şi pentru elevii cu nivel mediu de instruire $(16,29 \%)$, pentru ca această însuşire să constituie o prezență foarte importantă pentru un om religios la elevii cu nivel ridicat de instruire $(31,25 \%)$, aşa cum rezultă din tabelul 5 .

\section{Însuşiri ale omului religios, \\ Tabelul 5 în funcţie de nivelul de instruire al elevilor}

\begin{tabular}{|l|c|c|c|}
\hline \multirow{2}{*}{ Însuşiri ale omului religios } & \multicolumn{3}{|c|}{ Media } \\
\cline { 2 - 4 } & $\mathbf{5 - 6 , 9 9}$ & $\mathbf{7 - 8 , 9 9}$ & $\mathbf{9 - 1 0}$ \\
\hline să creadă în Dumnezeu (c) & 60 & 58,11 & 59,02 \\
\hline să meargă la biserică (b) & 26,15 & 29,88 & 22,22 \\
\hline să se roage (r) & $\mathbf{1 8 , 4 6}$ & 27,29 & 20,13 \\
\hline să fie iubitor de aproapele său (i) & $\mathbf{1 6 , 9 2}$ & $\mathbf{1 6 , 2 9}$ & $\mathbf{3 1 , 2 5}$ \\
\hline să fie smerit (s) & $\mathbf{1 0 , 7 6}$ & 17,64 & 21,52 \\
\hline să fie înţelept (î) & 15,38 & 14,11 & 13,54 \\
\hline
\end{tabular}

Datele arată o inversare a ierarhiei însuşirilor caracteristice omului religios în viziunea elevilor cu medii mari. Acesta trebuie să fie credincios, iubitor de semeni, să meargă la biserică, să fie smerit, rugător şi înţelept. Locul ocupat în listă de iubirea faţă de semeni poate fi pus şi pe seama unor modele pozitive observate de ei în societate şi mass-media.

Rezultatele obţinute în cazul elevilor cu nivel scăzut de instruire arată inclusiv o sărăcire a limbajului, capacitatea mai redusă de a opera cu conceptele din domeniul religios. 


\section{Analiza însuşirilor omului religios, în funcţie de confesiunea elevilor}

Ultima analiză prezentată în studiul de faţă are în vedere confesiunea elevilor implicaţi în cercetare ${ }^{8}$. Datele sunt trecute în tabelul 6.

Însuşirile omului religios,

Tabelul 6

în funcţie de confesiune

\begin{tabular}{|l|c|c|c|c|c|c|}
\hline $\begin{array}{l}\text { Însuşiri ale } \\
\text { omului } \\
\text { religios }\end{array}$ & $\begin{array}{c}\text { Orto- } \\
\text { doç̧i }\end{array}$ & $\begin{array}{c}\text { Roma } \\
\text { no- } \\
\text { catolici }\end{array}$ & $\begin{array}{c}\text { Greco- } \\
\text { catolici }\end{array}$ & $\begin{array}{c}\text { Refor- } \\
\text { maţi }\end{array}$ & $\begin{array}{c}\text { Bap- } \\
\text { tişti }\end{array}$ & $\begin{array}{c}\text { Penti- } \\
\text { costali }\end{array}$ \\
\hline $\begin{array}{l}\text { să creadă în } \\
\text { Dumnezeu } \\
\text { (c) }\end{array}$ & 58,47 & 57,14 & 53,84 & 65,38 & $\mathbf{8 4 , 1 5}$ & 25 \\
\hline $\begin{array}{l}\text { să meargă la } \\
\text { biserică (b) }\end{array}$ & 27,33 & $\mathbf{4 2 , 8 5}$ & 23,07 & 30,76 & 30,76 & 3,12 \\
\hline $\begin{array}{l}\text { să se roage } \\
\text { (r) }\end{array}$ & $\mathbf{2 4 , 7 0}$ & 14,28 & 7,69 & 19,23 & 15,38 & 12,5 \\
\hline $\begin{array}{l}\text { să fie iubitor } \\
\text { de aproapele } \\
\text { său (i) }\end{array}$ & 30,99 & 0 & 7,69 & 15,38 & 7,69 & $\mathbf{4 0 , 6 2}$ \\
\hline $\begin{array}{l}\text { să fie smerit } \\
\text { (s) }\end{array}$ & 19,29 & 0 & 15,38 & 7,69 & $\mathbf{2 3 , 0 7}$ & 18,75 \\
\hline $\begin{array}{l}\text { să fie înţelept } \\
\text { (i) }\end{array}$ & 13,74 & 0 & 7,69 & 19,23 & 7,69 & $\mathbf{2 1 , 8 7}$ \\
\hline
\end{tabular}

Valorile procentuale arată diferenţe semnificative în funcţie de confesiunea elevilor. Pentru creştinii ortodocşi, omul religios trebuie să fie credincios, iubitor de semeni, să meargă la biserică, să se roage, să fie smerit şi înţelept. Elevii romano-catolici şi cei de confesiune greco-catolică au creat profilul în jurul a trei însuşiri:

${ }^{8}$ Din punct de vedere confesional, eşantionul este reprezentativ la nivel naţional. 
credinţa şi participarea la biserică, la care se adaugă rugăciunea şi smerenia. În cazul elevilor reformaţi, doar cinci caracteristici au valori procentuale peste $10 \%$. Diferenţe pozitive şi negative mai mari cu peste 5 puncte procentuale se regăsesc în cazul însuşirii de a fi credincios $(65 \%)$, respectiv iubirea faţă de semeni (15\%).

În cazul elevilor aparţinând cultelor neoprotestante baptist şi penticostal, apar diferenţe semnificative la însuşirile precizate. Pentru baptişti cea mai importantă caracteristică este credinţa $(84,15 \%)$, urmată de participarea la biserică şi de smerenie, pe când penticostalii apreciază iubirea semenilor $(40,62 \%)$, credinţa $(25 \%)$ şi înţelepciunea $(21,87 \%)$.

Datele din tabelul 6 reflectă tipul de educaţie şi de misiune al fiecărei confesiuni creştine. Atenţia acordată credinţei, temă specifică cultului protestant este reliefată şi de datele cercetării, pentru elevii aparţinând cultului protestant şi celui baptist. Dacă elementele de practică religioasă reflectate în faptul de a merge la biserică reprezintă o valoare mai mare pentru elevii aparţinând cultelor romano-catolic, reformat şi baptist, în ceea ce priveşte însuşirea de a se ruga, aceasta reprezintă de departe o valoare promovată în cadrul Ortodoxiei, procentele în cadrul celorlalte confesiuni fiind la diferenţe semnificative.

Prezenţa în lista elevilor ortodocşi a iubirii faţă de semeni într-un procent mai mare decât participarea la biserică şi decât rugăciunea este şi urmare a accentuării în cadrul orelor de religie a acestei valori, dar şi a tipurilor de activităţi extraşcolare desfăşurate frecvent cu elevii, orientate înspre ajutorarea semenilor.

\section{Concluzii}

În plan pedagogic, datele cercetării reflectă nevoia susţinerii elevilor pentru a ajunge la o trăire a valorilor credinței prin care să depăşească statutul de religiozitate primară. Una dintre posibilele modalităţi de realizare a unui echilibru între elementele de religiozitate externă cu cele interne este legată de învăţarea şi exersarea rostirii rugăciunii împreună cu elevii, în diferite etape ale lecţiei şi ale zilei. Totodată, cântarea liturgică exersată în spaţiul 
şcolar şi realizată în cadrul eclesial în timpul diferitelor slujbe bisericeşti îi ajută pe elevi să îşi depăşească obstacolele interioare, care apar în primele etape ale manifestării publice a credinţei.

Chiar dacă ecuaţia personală a elevilor şi a profesorului este diferită în ceea ce priveşte raportul dintre înţelegerea şi manifestarea publică a credinţ̧ei, liceenii dovedesc la fiecare dintre clase aspecte remarcabile legat de atitudinea faţă de virtuţi şi preocuparea pentru practica religioasă, achiziţii şi finalităţi pe termen lung ale disciplinei religie.

Privită ca o şansă, raportarea elevilor la valorile religioase presupune din partea profesorului de religie, în colaborare cu mediul eclesial, nu doar răbdare şi consecvenţă, ci momente exemplare în care elevii sunt învăţaţi să se roage, să se comporte în acord cu valorile propriei credinţe, să se interiorizeze, pentru ca ei să simtă prezenţa şi lucrarea Duhului Sfânt.

\section{Bibliografie}

1. Cuciureanu, M., Velea, S. (coord.), Educaţia moral-religioasă în sistemul de educaţie din România, Bucureşti, Editura Didactică şi Pedagogică, 2012.

2. David, Daniel, Psihologia poporului român. Profilul psihologic al românilor într-o monografie cognitiv-experimentală, Iaşi, Editura Polirom, 2015.

3. Opriş, Dorin, Dimensiuni creştine ale pedagogiei moderne, Bucureşti, Editura Didactică şi Pedagogică, 2012.

4. Opriş, Dorin, Influences of the adolescent crisis in the parent-child relation, in Iulian Boldea (ed.), „Globalization and intercultural dialogue: multidisciplinary perspectives”, Proceedings of GIDNI 1, Târgu Mureş, Arhipelag XXI Press, 1/2014.

5. Opriş, D., Opriş, M., Teenagers'models of understanding suffering, in: European Journal of Science and Theology, 8:2, 2012.

6. Opriş, D., Opriş, M., Valori, modele şi aşteptări ale liceenilor din judeţul Alba, Cluj-Napoca, Editura Eikon, 2015.

7. Opriş, Monica, Adolescenţii de azi şi valorile religios-morale. Rolul sfântului ocrotitor al clasei în dezvoltarea spirituală a liceenilor, în Adrian Lemeni (coord.), ,Repere ale educaţiei creştine în teologia Sfântului Ioan Gură 
de Aur, actualizate în relaţia Biserică-Familie-Şcoală din contextul contemporan", Bucureşti, Editura Basilica, 2015.

8. Stăniloae, Dumitru, Ascetica şi mistica ortodoxă, Alba Iulia, Editura Deisis, Mănăstirea Sf. Ioan Botezătorul, 1993.

9. Voicu, Mălina (ed.), Credinţă şi practică religioasă în România, Institutul de Cercetare a Calităţii Vieţii, Grupul românesc pentru studiul valorilor sociale, „Valorile românilor”, Newsletter, nr. 2, februarie, 2009. 